Karol Ożóg*

\title{
Sustainability of Land and Buildings Database Records, Shown in the Example of Zabratówka village, Consolidated in 1995
}

\section{Introduction}

Human activity is causing permanent changes within the space. As a consequence of these changes, a huge diversity of soil usage is to be observed. Land and buildings database records, widely used in land resource management in Poland, amend all the detailed inventory rules, drawing up of a code of conduct, regulating change updating as well as land information-sharing. Such database exchange, between different land information systems is characterized by a different sustainability level, and therefore shows the tabular part containing detailed descriptive, cartographic results as outdated [5].

The biggest and the most common changes are to be observed in the agricultural land use. The size of the undergoing changes is not of the same importance when it comes to the property rights and the ways they are exercised. Particular circumstances relate to the changes in land-holding structure of lands under Austrian rule (Małopolskie, Podkarpackie and partially Śląskie Voivodship). After the emancipation of the peasants in 1848, the area was recognized as regulated by the law applicable to the succession. It subsequently led to its fragmentation (as a result of a farm employment and overpopulation) [4]. Changes were to come also in terms of the individual land legal status, which was regulated by the clarification of land status with regard to land ownership issues in 1971 [9]. In addition to the factors mentioned, general economic and social conditions play here a part together with the attractiveness or localization or residential development in the rural area.

This issue determines my thesis, and the change in land registers analysis, accompanied by the thorough evaluation will be shown in the example of Zabratówka village, consolidaed in 1995.

Zabratówka village was chosen deliberately. One of the main reasons was that it was consolidated, which corresponds with the sustainability level, confirmed by scientific researches as more reliable [1]. The second issue is the location. Zabratówka is situated near Rzeszów urban settlement.

\footnotetext{
* Podkarpackie Biuro Geodezji i Terenów Rolnych w Rzeszowie, Poland
} 


\section{Detailed Research}

The research covers different years, 1995-2013. Analysis is determined based on land consolidation data and land use register of 1995. Analysis and evaluation combine the fragmented nature of the farmland issues together with property rights matters. Every five years, subdivision and arable land matters were carefully examined.

The village of Zabratówka is situated in the south-eastern part of Rzeszów County, in Chmielnik Commune, which is illustrated in Figure 1.

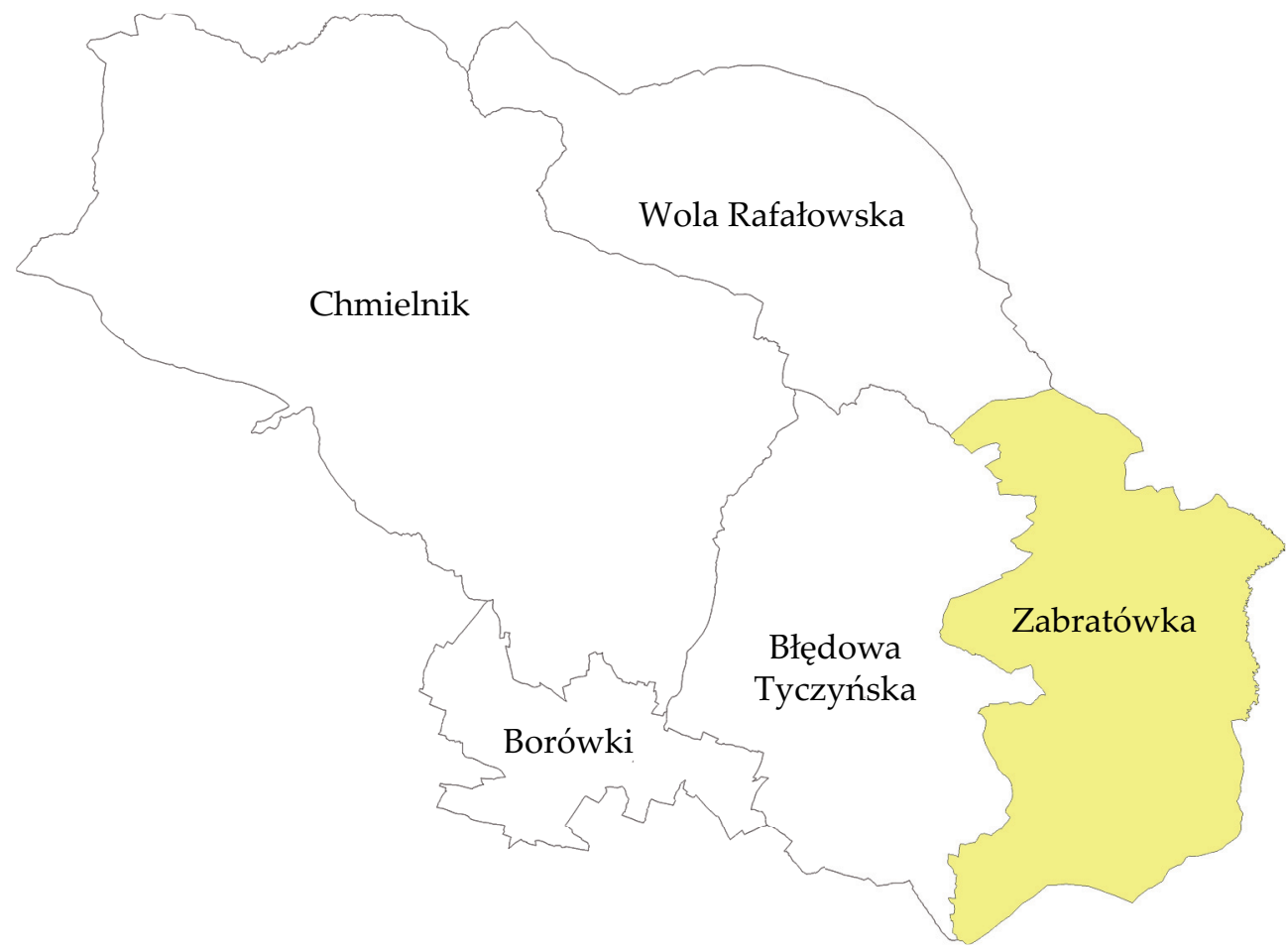

Fig. 1. Zabratówka location

Remoteness from the cities is calculated as: from Tyczyn $12 \mathrm{~km}$, from Rzeszów and Łańcut $15 \mathrm{~km}$. The village area covers 902 ha and is characterized by the diverse relief, with stream network and a large share of ravines. A part of the territory was threatened by landslides. Housing developments is dispersed through the area, but the biggest housing centres are to be concentrated in two locations: along the provincial road, district and municipal road. From the point of view of agronomic soil value, there is the predominance of IIIb and IVa criteria for arable lands and III and IV for grassland. In 1995 the village consisted of 683 people. There were also 295 farms and 188 of agricultural properties. The number of farms was decreased (to 2013) by 47 and amounted to 248 . The number of agricultural properties grew 
to 237 (increase about 49). In the sector under study, land belonging to individual owners prevailed, which is presented in Table 1. In 1995 land belonging to individual owners have occupied 692.53 ha accounting for $76.7 \%$ of the overall village area. After the consolidation, and deductions allowed, area belonging to individual owners was decreased by 12.39 ha. Accordingly, the roads have grown from 17.00 ha to 29.39 ha, accounting for $3.3 \%$ of the overall village area.

Table 1. Governance land structure of Zabratówka village in years 1995-2013

\begin{tabular}{|c|l|c|c|c|c|c|c||}
\hline \multirow{2}{*}{ No. } & \multirow{2}{*}{ Legal status } & \multicolumn{2}{|c|}{$\begin{array}{c}\text { Before land } \\
\text { consolidation 1995 }\end{array}$} & \multicolumn{2}{|c|}{$\begin{array}{c}\text { After land } \\
\text { consolidation 1996 }\end{array}$} & \multicolumn{2}{|c||}{ Area in 2013} \\
\cline { 3 - 8 } & & {$[\mathrm{ha}]$} & {$[\%]$} & {$[\mathrm{ha}]$} & {$[\%]$} & {$[\mathrm{ha}]$} & {$[\%]$} \\
\hline \hline 1 & State-owned forests & 127.20 & 14.1 & 126.83 & 14.1 & 129.46 & 14.3 \\
\hline 2 & $\begin{array}{l}\text { Land belonging to } \\
\text { individual owners }\end{array}$ & 692.53 & 76.7 & 680.37 & 75.4 & 712.20 & 78.9 \\
\hline 3 & Public roads & 17.00 & 1.9 & 29.39 & 3.3 & 29.39 & 3.3 \\
\hline 4 & $\begin{array}{l}\text { State water } \\
\text { resources }\end{array}$ & 7.23 & 0.8 & 7.84 & 0.9 & 8.06 & 0.9 \\
\hline 5 & $\begin{array}{l}\text { The State Treasury } \\
\text { (IV and IX criteria) }\end{array}$ & 58.40 & 6.5 & 57.9 & 6.4 & 23.21 & 2.6 \\
\hline \multicolumn{1}{|c|}{ Total } & 902.36 & 100.0 & 902.33 & 100.0 & 902.32 & 100.0 \\
\hline
\end{tabular}

Sources to support research: own calculations, consolidated records, land and buildings database records

The forested area (state owned forests) accounting of $14.3 \%$ of the overall village area in 2013, increased (over the time of 19 years) by 2.26 ha $(0.2 \%)$, as citing data from the Agency of Agricultural Properties of State Treasury.

Apart from legal status mentioned, a rather high share of $6.5 \%$ of the overall village area (in 1995) belonged to the State Treasury. Until 2013, the area was decreased (from 58.40 ha to $23.21 \mathrm{ha}$ ) accounting of $2.6 \%$ of the overall village area. This land complex is managed by the Agency of Agricultural Properties of State Treasury and has not been sold so far as a result of the unresolved legal status. Owing to the reduction (after 1996) in the area of land belonging to The State Treasury, land belonging to individual owners have occupied the number of 712.20 ha in 2013, accounting of 78.9 of the overall village area. After land consolidation, in the governance land structure, minor changes are to be observed, including the natural persons purchases of the State Treasury owned land. Accordingly a change of land ownership within the individual sector is to be present, which is illustrated in Table 2. It follows from the data presented in the above table that, after the land consolidation, land belonging to natural persons was recognized in 768 registration rankings.

In the investigation period, the number of registration rankings was increased by 183. Looking at this growth, every five years, it has to be stated that it was varied. Attention should be drawn to the whole change of registration rankings (which is of 130 ranks), accounting of $71.0 \%$ of all observed changes. The division was distinct 
in 53 of registration rankings. The observed changes in the governance land structure may be considered as of a great size, in comparison to the ones presented in the study [1].

Table 2. Governance land structure in years 1996-2013

\begin{tabular}{|c|c|c|c|c|c|c|c|c|c|c|}
\hline \multirow{4}{*}{ No. } & \multirow{4}{*}{$\begin{array}{l}\text { Period of } \\
\text { changes }\end{array}$} & \multirow{4}{*}{$\begin{array}{l}\text { Number of } \\
\text { registration } \\
\text { rankings }\end{array}$} & \multirow{4}{*}{$\begin{array}{l}\text { Number } \\
\text { of } \\
\text { changes }\end{array}$} & \multirow{4}{*}{$\begin{array}{c}\text { Number } \\
\text { of changes } \\
\text { (percentage } \\
\text { rate) }\end{array}$} & \multicolumn{6}{|c|}{ Structure of ranking divisions } \\
\hline & & & & & \multirow{2}{*}{\multicolumn{2}{|c|}{$\begin{array}{l}\text { whole } \\
\text { change of } \\
\text { registration } \\
\text { rankings }\end{array}$}} & \multicolumn{4}{|c|}{ ranking divisions } \\
\hline & & & & & & & \multicolumn{2}{|c|}{ two parts } & \multicolumn{2}{|c|}{ three parts } \\
\hline & & & & & $\begin{array}{l}\dot{\Xi} \\
\text { ఏ్ } \\
\Xi\end{array}$ & {$[\%]$} & 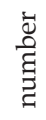 & {$[\%]$} & $\begin{array}{l}\text { ปे } \\
\text { है } \\
\text { こ }\end{array}$ & {$[\%]$} \\
\hline 1 & 1996-2001 & $768-810$ & 42 & 23.0 & 27 & 64.3 & 13 & 31.0 & 2 & 4.7 \\
\hline 2 & 2002-2006 & $810-865$ & 55 & 30.0 & 41 & 74.5 & 11 & 20.0 & 3 & 5.5 \\
\hline 3 & 2007-2011 & $865-940$ & 75 & 41.0 & 56 & 74.6 & 14 & 18.7 & 5 & 6.7 \\
\hline 4 & 2012-2013 & $940-951$ & 11 & 6.0 & 6 & 54.5 & 3 & 27.3 & 2 & 18.2 \\
\hline \multicolumn{3}{|c|}{ Total } & 183 & 100.0 & 130 & 71.0 & 41 & 22.4 & 12 & 6.6 \\
\hline
\end{tabular}

Sources to support research: own calculations, land and buildings database records

The direction of the changes in the private sector is a reflection of the geographical location: closeness to Rzeszów urban settlement. The influence on the proximity relates to social and historical circumstances. It build employment pathways for people, who settled willingly in the new environment. Constant generational change effects on farm ownership and succession issues, where except for village residents, Rzeszów residents play a role. A tendency for the purchase of agricultural land and building plots is triggered by the possibility to provide a cheaper accommodation (due to high prices of city located flats). Taking into the account 183 database records, 103 land owners reside in Rzeszów, which is illustrated in Table 3.

The concept of land owners who own land but live outside the village area was introduced by Rabczuk [8]. To distinguish the difference [5] two criteria are adopted:

1. owning land by land owners who live outside the village area (nonresident owners),

2. owning land outside the village area by village residents (resident owners).

As it follows from the data presented in Table 3, the number of nonresident owners increased from 429 in 1996 to 583 in 2013, accounting of a 36\% increase. With the exception of Rzeszów, in individual villages, minor changes are to be observed. The increase in the number of nonresident owners taken together, influences the database records. The changes do not cause considerable hardship for the updating process of the database, but effects on the parcel registering process. 
Table 3. Size of non-resident owners in years 1996-2013

\begin{tabular}{|c|c|c|c|c|c|c|}
\hline \multirow{3}{*}{ No. } & \multirow{3}{*}{$\begin{array}{l}\text { Names of villages, } \\
\text { from where, none } \\
\text { resident owners } \\
\text { come from }\end{array}$} & \multicolumn{4}{|c|}{ Number of nonresident owners } & \multirow{3}{*}{$\begin{array}{c}\text { Personal } \\
\text { data changes }\end{array}$} \\
\hline & & \multicolumn{2}{|c|}{$\begin{array}{l}\text { after land consolidation in } \\
1996\end{array}$} & \multicolumn{2}{|c|}{ in 2013} & \\
\hline & & number & {$[\%]$} & number & [\%] & \\
\hline 1 & Rzeszów & 31 & 7.2 & 134 & 23.0 & +103 \\
\hline 2 & Handzlówka & 120 & 28.0 & 118 & 20.2 & -2 \\
\hline 3 & Albigowa & 41 & 9.5 & 43 & 7.4 & +2 \\
\hline 4 & Błędowa Tyczyńska & 38 & 8.9 & 36 & 6.2 & -2 \\
\hline 5 & Wola Rafałowska & 38 & 8.9 & 37 & 6.3 & -1 \\
\hline 6 & Chmielnik & 25 & 5.8 & 24 & 4.1 & -1 \\
\hline 7 & Eańcut & 20 & 4.7 & 26 & 4.6 & +6 \\
\hline 8 & Grzegorzówka & 19 & 4.4 & 16 & 2.7 & -3 \\
\hline 9 & Hyżne & 13 & 3.0 & 13 & 2.2 & 0 \\
\hline 10 & Markowa & 12 & 2.8 & 9 & 1.5 & -3 \\
\hline 11 & Tyczyn & 3 & 0.7 & 7 & 1.2 & +4 \\
\hline 12 & Husów & 2 & 0.5 & 4 & 0.7 & +2 \\
\hline 13 & Malawa & 0 & 0.0 & 3 & 0.5 & +3 \\
\hline 14 & $\begin{array}{l}\text { Remaining } \\
\text { nonresident owners } \\
\text { (37 localisations) }\end{array}$ & 67 & 15.6 & 113 & 19.4 & +46 \\
\hline & Total & 429 & 100.0 & 583 & 100.0 & +154 \\
\hline
\end{tabular}

Sources to support research: own calculations, land and buildings database records

As a result of a constant land transfer in the example of Zabratówka, concerning not only the whole change of registration rankings but also the number of parcels included, its number has increased in general [5,7]. Detailed information on the size and number of the registered parcel of land is shown in Table 4 


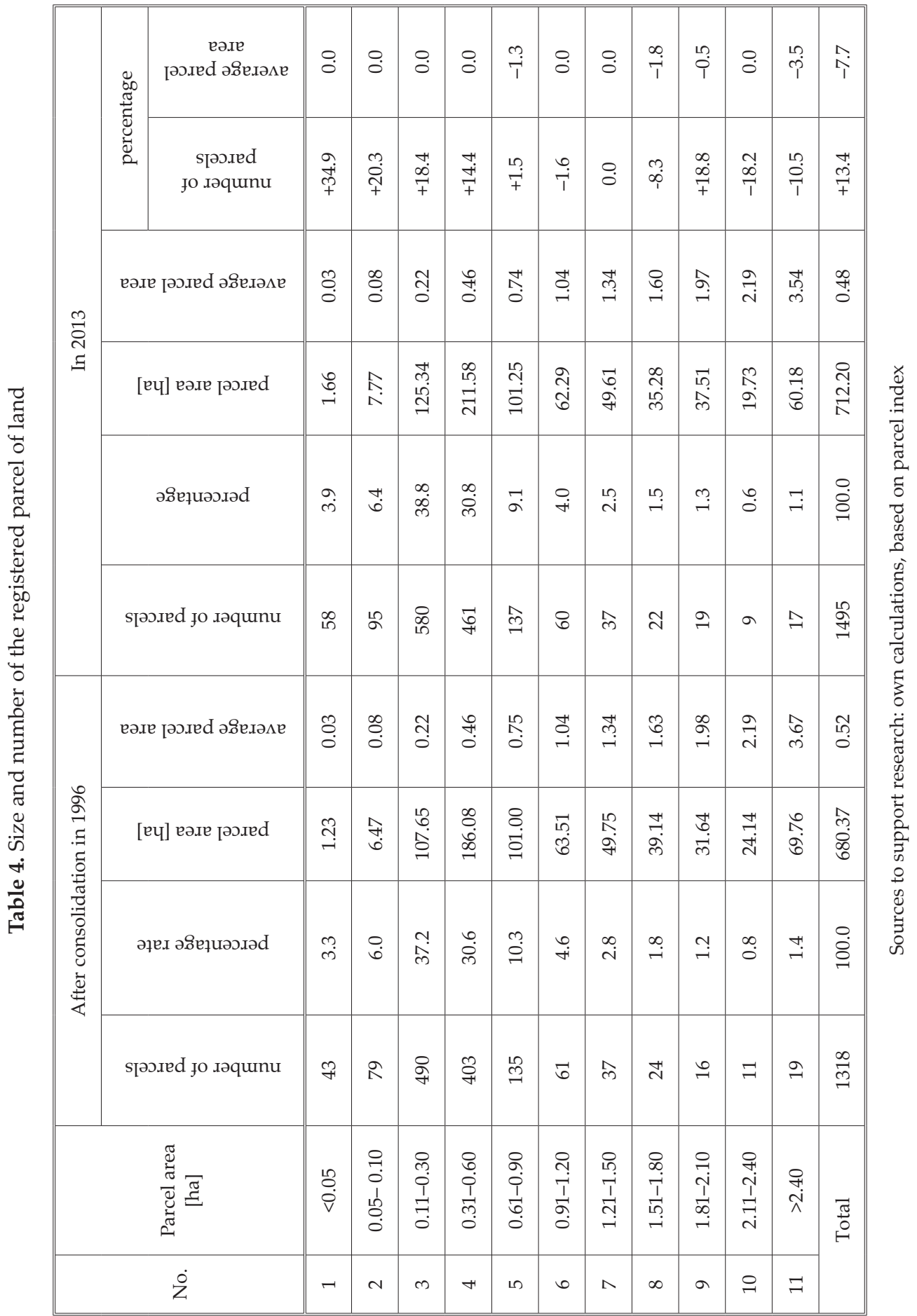


Reffering to data, until the end of 2013 the plot number in Zabratówka has increased by 177 , which is $13.4 \%$ in comparison to1996. Mainly small plots were subdivided. It refers in particular to parcels in the two first ranges: up to 0.30 ha. Especially large number of parcels (90) comes from the range of $0.11-0.30$ ha, most commonly building plots. Also the number of parcels in the $0.31-0.60$ range has increased, up to 58. The most characteristic phenomenon is the increase in the number of small plots, which are designed for construction purposes, which is a good sign. Accordingly, the subdivision of agricultural land has negative consequences, like plot fragmentation. Such a subdivision effected on the size, the average plot area in the individual sector decreased from 0.52 ha to 0.48 ha. In the analyzed ranges, up to $0.90 \mathrm{ha}$, the decrease in the average parcel surface is not significant. It gives visibility only with large surfaces.

Apart from the listed changes, the scope of the arable land is illustrated in Table 5.

Table 5. Changes in the scope of the arable land in years 1996-2013

\begin{tabular}{|c|c|c|c|c|c|c|}
\hline \multirow{2}{*}{ No. } & \multirow{2}{*}{ Land type } & \multicolumn{2}{|c|}{ After consolidation in 1996} & \multicolumn{2}{|c|}{ In 2013} & \multirow{2}{*}{$\begin{array}{l}\text { Number of } \\
\text { changes [ha }\end{array}$} \\
\hline & & [ha] & {$[\%]$} & [ha] & {$[\%]$} & \\
\hline 1 & Agricultural area & 309.17 & 34.3 & 277.99 & 30.8 & -31.18 \\
\hline 2 & Permanent meadows & 18.88 & 2.1 & 13.83 & 1.5 & -5.05 \\
\hline 3 & Pastures & 190.07 & 21.0 & 125.04 & 13.9 & -65.03 \\
\hline 4 & Orchards & - & - & 7.90 & 0.9 & - \\
\hline 5 & Water & 7.43 & 0.8 & 8.06 & 0.9 & +0.63 \\
\hline 6 & Built agricultural area & - & - & 25.27 & 2.8 & +25.27 \\
\hline \multicolumn{2}{|c|}{ Agricultural area (total) } & 525.55 & 58.2 & 458.09 & 50.8 & -67.46 \\
\hline \multicolumn{2}{|c|}{ Wasteland } & 0.52 & 0.1 & 1.04 & 0.1 & +0.52 \\
\hline 1 & Woodland & 343.33 & 38.0 & 350.52 & 38.8 & +7.19 \\
\hline 2 & Trees and bushes & 3.54 & 0.4 & 55.08 & 6.1 & +51.54 \\
\hline \multicolumn{2}{|c|}{ Total (trees and bushes, woodland) } & 346.87 & 38.4 & 405.60 & 45.0 & +58.73 \\
\hline 1 & Residential area & - & - & 6.05 & 0.7 & - \\
\hline 2 & Built area & - & - & 1.82 & 0.2 & - \\
\hline 3 & Recreation and rest area & - & - & 0.34 & 0.0 & - \\
\hline \multicolumn{2}{|c|}{ Total (built and urban area) } & - & - & 8.21 & 0.9 & - \\
\hline \multicolumn{2}{|c|}{ Roads } & 29.39 & 3.3 & 29.39 & 3.3 & 0.0 \\
\hline \multicolumn{2}{|c|}{ Total } & 902.33 & 100.0 & 902.32 & 100.0 & - \\
\hline
\end{tabular}

Sources to support research: own calculations, land and buildings database records 
Based on the data presented, the most considerable changes are to be observed in the agricultural area. The change in the number of pastures is the most striking (65.03 ha), size of the arable land is also relatively huge (31.18 ha). These two types of areas include: built agricultural area, of the size of $25.27 \mathrm{ha}$, which was never addressed in the documentation of 1996.

Concluding, size of agricultural land has decreased by 67.46 ha. Consequently, terrain characterized as partially grown with trees and bushes has evolved (by $51.54 \mathrm{ha}$ ), which is a sign of agricultural production withdrawal. Such an expanding number of areas grown with trees and bushes is common in the and foothill and mountain areas, which is scientifically proven $[3,6]$ and at the same time, destabilise the arable land classification. The updating process of the database referring to the average size of the parcel is strictly applied, whereas agricultural area information is not being enforced.

\section{Evaluation}

Sustainability of land and buildings database records analysis, in the example of the consolidated village, led to the conclusion that:

1. The observed changes, over the years, can be categorized as significant. A tendency for the purchase and land transfer of Rzeszów residents definitely was a key issue.

2. The increased number of nonresident owners from Rzeszow, together with the location as well as the vicinity of the examined village also played a part.

3. Parcel subdivision and the increase in the plot number was also an important issue.

4. The most characteristic phenomenon was the increase in the number of small plots, which were designed for construction purposes.

5. The updating process of the database is constantly monitored, in particular in the land registers.

6. Although the changes reffering to the arable land are of low sustainability, especially in the end foothill and mountain areas, they do destabilise the land register data.

Finally, on the basis of a research conducted, it has to be stated, that the sustainability of land and buildings database records, shown in the example of Zabratówka village, consolidated in 1995, and located in the vicinity of a significant industrial centre, is of a considerably less stability level than the one of a typical agricultural village, which is scientifically proven. 


\section{References}

[1] Grabowski M.: Analiza zmian w strukturze przestrzennej gruntów indywidualnych we wsiach scalonych gminy Wietrzychowice. Scalenia gruntów podstawa rozwoju obszarów wiejskich rozdrobnionego rolnictwa południowo wschodniej Polski. Zeszyty Towarzystwa Rozwoju Obszarów Wiejskich, Rzeszów 2005.

[2] Noga K.: Analiza międzywioskowej szachownicy gruntów na przykładzie wsi położonych w górnym dorzeczu Soły. Zeszyty Naukowe AR Kraków nr 133, Sesje Naukowe nr 7, Kraków 1977.

[3] Noga K.: Kierunki zmian w użytkowaniu gruntów w beskidzkiej zlewni Soły. Zeszyty Naukowe AR Kraków nr 382, Kraków 1977.

[4] Noga K.: Metodyka oceny struktury przestrzennej gruntów gospodarstw rolnych przed i po scaleniu. Scalenia gruntów podstawa rozwoju obszarów wiejskich rozdrobnionego rolnictwa południowo wschodniej Polski. Zeszyty Towarzystwa Rozwoju Obszarów Wiejskich, Rzeszów 2005.

[5] Noga K.: Ocena stabilności informacji zawartych w ewidencji gruntów. Sekcja Fotogrametrii i Teledetekcji Komitetu Geodezji PAN Kraków, Kraków 1997.

[6] Noga K., Kubowicz H.: Określenie kierunków zmian użytkowania gruntów w terenach górskich. Międzynarodowa Konferencja Naukowa ELWIRO 2003, Zeszyty Naukowe AR w Krakowie, series: Inżynieria Środowiska, z. 24, Kraków 2003.

[7] Noga K., Leń P.: Analiza rozdrobnienia gruntów indywidualnych we wsiach powiatu Brzozów. Infrastruktura i Ekologia Terenów Wiejskich, nr 3, 2010, pp. 55-64.

[8] Rabczuk I.: Problem różniczan w pow. proszowickim, woj. krakowskie. [in:] Aktualne zagadnienia geodezji urzadzeniowo-rolnej, Wydawnictwo Czasopism Technicznych NOT, Warszawa 1968, pp. 65-70.

[9] Ustawa z dnia 26 października 1971 r. o uregulowaniu własności gospodarstw rolnych. Dz.U. nr 27 poz. 250 repealed. 